\title{
UJI KUALITAS GELATIN DARI TULANG IKAN TUNA SIRIP KUNING (Thunnus albacares) MENGGUNAKAN JENIS ASAM YANG BERBEDA
}

\author{
Gelatin Quality Test from Yellow Fins Tuna Bone (Thunnus albacares) Using Different Types of Acid
}

\author{
Rini Safitri1, Kobajashi T. Isamu1, Nur Illiyin Akib2 \\ 1Jurusan Teknologi Hasil Perikanan, Fakultas Perikanan dan IImu Kelautan Universitas Halu Oleo, Kendari, \\ Sulawesi Tenggara, Indonesia \\ 2Jurusan Farmasi, Fakultas Farmasi Universitas Halu Oleo, Kendari, Sulawesi Tenggara, Indonesia \\ *Email korespondensi: rinisafitri@gmail.com (Telp: +6282348805290) \\ Diterima: 25 September/ Disetujui 30 Oktober 2019
}

Cara sitasi: Safitri R, Isamu KT, Akib NI. 2019. Uji kualitas gelatin dari tulang ikan tuna sirip kuning (Thunnus albacares) menggunakan jenis asam yang berbeda. Jurnal Fish Protech. 2(2):218-225.

\begin{abstract}
The Aims of this studi was to determine the quality of gelatin from the yellowfin tuna bone of different acid types and to know the effect of the use of acid as an extraction material to the quality of the yellow fin tuna gelatin. This study uses a variety of different acid concentrations, namely solution of hydrochloric acid 4\% (A1), acetate 4\% acid (A2) and 4\% sulphuric acid (A3). The study made use of the complete random draft (RAL) consisting of 3 treatments and 3 times repeated. Data on the observation result is analyzed using ANOVA (Analysis of Variance) at 95\%, if there is a real difference $(P>0.05)$ then the test is carried out with a test of DMRT (Duncan Multiple Range Test) in the real standard $95 \%$. Analysis of sensory testing, proximate composition, $\mathrm{pH}$ value tests and lowliness. The highest consecutive sensory values (aroma and color) are found in the treatment of (A1) and (A3) with a value of 6.2 and 6.1. The highest consecutive proximate composition values (moisture content, ash content, and protein levels) are noted in the (A2) and (A1) treatments with values of 12.51, 6.60 and 50.64. Highest $\mathrm{pH}$ value on treatment of (A1) and (A2) with value 5 . The highest yield values in the (A3) treatment with a value of $3 \%$. From statistics of real difference test (DMRT) indicates that there is no noticeable difference in the gelatin color and aroma of the yellowfin Tuna fish bones by using altered acid types.
\end{abstract}

Keywords: Gelatin, Lowliness, Proximate, PH value, sensory test, Tuna bone, and

ABSTRAK

Penelitian ini bertujuan untuk mengetahui kualitas gelatin dari tulang ikan tuna sirip kuning dari jenis asam yang berbeda dan untuk mengetahui pengaruh penggunaan asam sebagai bahan pengekstraksi terhadap kualitas gelatin ikan tuna sirip kuning. Penelitian ini menggunakan variasi konsetrasi asam yang berbeda yaitu larutan asam klorida $4 \%$ (A1), asam asetat4\% (A2) dan asam sulfat 4\% (A3). Penelitian ini menggunakan Rancangan Acak Lengkap (RAL) yang terdiri dari 3 perlakuan dan 3 kali ulangan. Data hasil pengamatan dianalisa menggunakan ANOVA (Analysis of Variance) pada taraf $95 \%$, apabila terdapat beda nyata $(P>0,05)$ maka dilakukan uji lanjut dengan uji DMRT (Duncan Multiple Range Test) pada taraf nyata 95\%. Analisis uji sensori, komposisi proksimat, uji nilai pH dan rendemen. Nilai sensori tertinggi berturut-turut (aroma dan warna) terdapat pada perlakuan (A1) dan (A3) dengan nilai 6.2 dan 6.1. Nilai komposisi proksimat berturut-turut tertinggi (kadar air, kadar abu, dan kadar protein) terdapat pada perlakuan (A2) dan (A1) dengan nilai 12.51, 6.60 dan 50.64. Nilai pH tertinggi pada perlakuan (A1) dan (A2) dengan nilai 5. Nilai rendemen tertinggi pada perlakuan (A3) dengan nilai 3\%. Dari statistik uji beda nyata (DMRT) menunjukkan bahwa tidak terdapat perbedaan nyata pada warna dan aroma gelatin dari tulang ikan Tuna sirip kuning dengan menggunakan jenis asam yang berbeda.

Kata kunci: Gelatin, Nilai pH,Proksimat, Rendemen, Tulang Ikan Tuna, dan Uji Sensori 


\section{PENDAHULUAN}

Ikan tuna jenis Thunnus albacores merupakan salah satu hasil perikanan di Indonesia yang potensial. Sulawesi Tenggara merupakan daerah penghasil ikan tuna, berdasarkan data BPS pada tahun 2019 hasil tangkap ikan tuna mencapai 7.492 ton. Ikan tuna banyak dikonumsi oleh masyarakat karena selain rasanya yang gurih juga memiliki kandungan gizi yang cukup tinggi. Tuna sirip kuning banyak diolah menjadi beberapa jenis produk olahan perikanan seperti bakso, somay, ikan asap, katsobushi, tuna loin dan lain sebagainya.

Produk-produk olahan ini menghasilkan limbah berupa tulang. Limbah perikanan jika tidak ditangani dengan baik akan menyebabkan dampaknegatif terhadap lingkungan dan manusia. Selama ini tulang ikan sebagai limbah belum termanfaatkan secara optimal, yaitu hanya digunakan untuk bahan pembuatan pakan atau pupuk sehingga nilai ekonomisnya sangat kecil. Sementara, tulang dan kulit ikan tuna banyak mengandung kolagen yang dapat diolah menjadi gelatin (Nurilmala et al., 2017).

Lombu et al. (2015) menyatakan bahwa gelatin merupakan salah satu jenis protein yang banyak diperoleh dari kolagen alami yang terdapat pada kulit dan tulang. Gelatin memiliki sifat khas, yaitu dapat berubah secara reversible dari bentuk sol ke gel, mengembang dalam air dingin, dapat membentuk film, mempengaruhi viskositas suatu bahan serta dapat melindungi sistem koloid. Sifat gelatin tersebut membuat kebutuhan gelatin dalam industri pangan maupun non pangan terus meningkat.

Penggunaan gelatin dalam bahan pangan dan non pangan kekuatan gel,viskositas dan titik leleh merupakan sifat khas gelatin yang sangat penting. Sifat-sifat ini dipengaruhi oleh beberapa faktor, seperti konsentrasi larutan gelatin, waktu pemanasan gel, suhu pemanasan gel, $\mathrm{pH}$ dan kandungan asam (Norland, 1990). Selain itu teknik ekstraksi seperti tingkat keasaman, jenis larutan perendaman, lama perendaman dan suhu ekstraksi diduga mempengaruhi sifat-sifat gelatin tersebut.
Gelatin terbagi menjadi dua tipe berdasarkan perbedaan proses pengolahannya, yaitu tipe $A$ dan tipe $B$. Pembuatan gelatin tipe $A$, bahan baku diberi perlakuan perendaman dalam larutan asam sehingga proses ini dikenal dengan sebutan proses asam, sedangkan dalam pembuatan gelatin tipe $B$, perlakuan yang diaplikasikan adalah perlakuan basa (Al-Saidi et al., 2010). Secara ekonomis, proses pembuatan gelatin dengan perendaman asamlebih disukai dibandingkan proses basa.

Proses pembuatan gelatin dengan perendaman dalam larutan asam membutuhkan waktuyang lebih singkat dibanding dengan perendaman dalam larutan basa karena asam mampu mengubah serat kolagen triple heliks menjadi rantai tunggal sedangkan larutan perendam basa hanya mampu menghasilkan rantai ganda, sehingga pada waktu yang sama kolagen yang dihidrolisis oleh larutan asam lebih banyak daripada larutan basa (Junianto, 2006).

\section{METODE PENELITIAN}

\section{Alat dan Bahan}

Alat yang digunakan dalam penelitian ini terdiri dari hot plate (faithful), waterbath (memmert), oven (memmert), desikator (duran), spektrofotometer (unicam), gelas beaker (pyrex), gelas ukur (pyrex), kertas saring whatman no.4, ayakan 100 mesh, pisau (lion star), timbangan analitik (matrix), blender (miyako), talang besi (stainless), plastik tahan panas, kertas $\mathrm{pH}$, kaca preparat, dan alat pengujian proksimat.

Bahan baku yang digunakan pada penelitian ini adalah tulang ikan tuna sirip kuning, air, $\mathrm{CH}_{3} \mathrm{COOH}$ /asam asetat (fluka), $\mathrm{HCl} /$ asam klorida (merck), $\mathrm{H}_{2} \mathrm{SO} 4$ /asam sulfat (merck), aquades.

\section{Rancangan Penelitian}

Penelitian ini menggunakan Rancangan Acak Lengkap (RAL) yang terdiri dari 3 perlakuan yaitu $A 1$ (perendaman denganasam klorida 4\%), A2 (perendaman dengan asam asetat $4 \%$ ), dan $A 3$ (perendaman dengan asam sulfat4\%). Masing-masing 
perlakuan dilakukan tiga kali ulangan, sehingga diperoleh jumlah satuan percobaan sebanyak 9 unit.

\section{Prosedur Penelitian}

\section{Preparasi Sampel}

Sampel tulang ikan tuna sirip kuningyang digunakan diambil dari limbah hasil pengolahan penggilingan daging di Pasar Sentral Kota Kendari, Jl. Katambak, Dapu-Dapura, Kendari Barat, Kota Kendari, Sulawesi Tenggara. Tulang ikan ditempatkan dalamstyrofoam, dibawa ke kendari menggunakan kapal laut, setelah itu dibawa ke laboratorium untuk dilakukan pencucian, pembersihan dari sisa-sisa daging yang masih menempel dan penimbangan.

\section{Tahap Degreasing (Penghilangan Lemak)}

Tulang ikan sebanyak $500 \mathrm{~g}$ direbus dalam air $1000 \mathrm{ml}$ pada suhu $70^{\circ} \mathrm{C}$ selama 30 menit.Selanjutnya dilakukan proses pembersihan yaitu pencucian menggunakan air. Kemudian dilakukan pengecilan ukuran tulang ikanmenjadi $3 \mathrm{~cm}$ menggunakan pisau dan dikeringkan pada suhu $65^{\circ} \mathrm{C}$ selama 6 jam.

Tahap Demineralisasi (Penghilangan Kalsium)

Potongan tulang ikan sebanyak $500 \mathrm{~g}$ dimasukkan ke dalam gelas kimia yang masingmasing berisi larutan asam klorida 4\% (A1), asam asetat 4\% (A2) dan asam sulfat 4\% (A3) dengan rasio 1:7 selama 48 jam. Sehingga dihasilkan tulang lunak yang disebut ossein.Ossein dinetralkan pHnya (7) dengan cara mengaliri ossein dengan air mengalir selama \pm 1 jam, lalu diperiksa dengan kertas
$\mathrm{pH}$.Setelah mendekati $\mathrm{pH}$ netral (7) ossein tersebut dibilas.

\section{Tahap Ekstraksi}

Ossein sebanyak $150 \mathrm{~g}$ diekstraksi menggunakan aquades dengan cara dimaasukkan ke dalam waterbath pada suhu $80^{\circ} \mathrm{C}$ selama 4 jam dengan perbandingan 1:3. Kemudian ekstrak yang dihasilkan disaring menggunakan kertas saring whatman No. 4 sehingga menghasilkan filtrat. Selanjutnya dilakukan proses pengeringan dengan cara ekstrak dituang ke dalam talang besi yang telah dilapisi dengan palstik tahan panas dan di masukkan ke dalam oven pada suhu $65^{\circ} \mathrm{C}$ selama 48 jam hingga diperoleh ekstrak kering. Ekstrak yang telah kering didinginkan pada suhu ruang, selanjutnya ekstrak kering yang menempel pada plastik dibersihkan hingga diperoleh bubuk gelatin. Bubuk gelatin yang diperolah selanjutnya dilakukan analisis kualitas gelatin.

\section{Parameter Uji}

Uji sensori (SNI. 01-2346. 2006), Analisis uji kimia meliputi kadar abu (AOAC, 1995), kadar air (AOAC, 1995),kadar protein (AOAC, 1995), Pengukuran pH (Rahayu, 2008), dan Analisis Total Rendemen Metode Gravimetri (AOAC, 1995).

\section{Analisis Data}

Data yang diperoleh dianalisis menggunakan analisis of varians (ANOVA), jika hasil analisis menunjukan beda nyata maka dilakukan uji Duncan's Multiple Range Test (DMRT) untuk mengetahui beda nyata antar perlakuan dengan tingkat kepercayaan $95 \%(\alpha=0,05)$.

\section{HASIL DAN PEMBAHASAN}

Data hasil penelitian analisis total rendemen disajikan pada Tabel 1.

Tabel 1. Hasil analisis total rendemen gelatin

\begin{tabular}{llll}
\hline Perlakuan & $\begin{array}{l}\text { Berat Bahan } \\
\text { Baku }(\mathrm{g})\end{array}$ & $\begin{array}{l}\text { Berat Sampel } \\
(\mathrm{g})\end{array}$ & $\begin{array}{l}\text { Total } \\
\text { Rendemen }(\%)\end{array}$ \\
\hline $\mathrm{HCl}^{*}$ & 500 & 9,1504 & 1,83 \\
$\mathrm{CH}_{3} \mathrm{COOH}^{*}$ & 500 & 10,3484 & 2,06 \\
$\mathrm{H}_{2} \mathrm{SO}_{4}{ }^{*}$ & 500 & 15,0129 & 3 \\
\hline
\end{tabular}

Keterangan : * : Perendaman jenis asam selama 48 jam dengan konsentrasi $4 \%$ 
Hasil rerata penilaian uji sensori tiap perlakuan terhadap parameter warna dan aroma disajikan pada Tabel 2.

Tabel 2. Nilai rata-rata uji sensori gelatin

\begin{tabular}{lccc}
\hline \multirow{3}{*}{ Parameter } & \multicolumn{3}{c}{ Perlakuan } \\
\cline { 2 - 4 } Warna & $\mathrm{HCl}^{*}$ & $\mathrm{CH}_{3} \mathrm{COOH}^{*}$ & $\mathrm{H}_{2} \mathrm{SO}_{4}{ }^{*}$ \\
\cline { 2 - 4 } Aroma & $4,8 \pm 0,62$ & $4,43 \pm 0,47$ & $6,01 \pm 0,84$ \\
\hline
\end{tabular}

Keterangan : * : Perendaman jenis asam selama 48 jam dengan konsentrasi $4 \%$

Hasil analisis kimia glatin meliputi kadar abu, kadar air, kadar protein dan nilai pH disajikan pada Tabel 3.

Tabel 3. Analisis kimia gelatin

Parameter

Perlakuan

\begin{tabular}{|c|c|c|c|}
\hline \multirow[b]{3}{*}{$\begin{array}{l}\text { Abu (\%) } \\
\text { Air (\%) }\end{array}$} & \\
\hline & $\mathrm{HCl}^{*}$ & $\mathrm{CH}_{3} \mathrm{COOH}^{*}$ & $\mathrm{H}_{2} \mathrm{SO}_{4}{ }^{*}$ \\
\hline & $\begin{array}{l}9,87 \\
6,60\end{array}$ & $\begin{array}{l}12,51 \\
4,53\end{array}$ & $\begin{array}{l}6,95 \\
6,43\end{array}$ \\
\hline $\begin{array}{l}\text { Protein (\%) } \\
\text { pH }\end{array}$ & $\begin{array}{l}50,64 \\
5\end{array}$ & $\begin{array}{l}37,76 \\
5\end{array}$ & $\begin{array}{l}25,88 \\
4\end{array}$ \\
\hline
\end{tabular}

Keterangan : * : Perendaman jenis asam selama 48 jam dengan konsentrasi $4 \%$

\section{Rendemen}

Berdasarkan Tabel 1 dapat dilihat bahwa rendemen tertinggi terdapat pada perendaman dengan asam sulfat yaitu $3 \%$ sedangkan rendemen terendah dihasilkan dengan perendaman asam klorida yaitu $1,83 \%$ hal ini diduga karena jumlah ion $\mathrm{H}_{+}$yang menghidrolisis kolagen tulang ikan tuna berbeda-beda tergantung jenis asam yang digunakan. Menurut Ridhay et al. (2016) semakin banyak ion $\mathrm{H}+$ semakin meningkat jumlah rendemen. Hal ini disebabkan oleh adanya proses pengikatan mineral kalsium dalam tulang ikan sehingga menyebabkan terbebasnya kolagen dalam tulang ikan tersebut.

Rendemen terendah dihasilkan dengan perendaman asam klorida yaitu $1,83 \%$ hal ini disebabkan konsentrasi asam klorida yang digunakan sedikit. Menurut penelitian Nurilmala et al. (2006), semakin banyak konsentrasi asam klorida yang diberikan , maka rendemennya semakin tinggi.

Nilai rendemen gelatin pada penelitian ini lebih rendah dari rendemen gelatin paada penelitian Triklasani (2012) dimana hasil penelitiannya nilai rendemen yang dihasilkan berkisar antara 5,32-13,33 $\%$ dengan lama perendaman 12, 18 dan 24 jam. Perbedaan nilai rendemen tersebut diduga dipengaruhi oleh lama perendaman tulang ikan.
Menurut Hintelwalder (1977) menyatakan bahwa jika lama perendaman atau waktu perendaman tidak dilakukan dengan baik dan tepat maka akan terjadi kelarutan kolagen yang menghasilkan nilai rendemen menjadi rendah.

\section{Uji sensori}

\section{Warna}

Warna gelatin yang dihasilkan pada penelitian ini sesuai standar SNI No. 06-3735-1995 dengan kriteria tidak berwarna sampai kekuningan kesesuaian ini diduga dipengaruhi oleh kesegaran bahan baku pembuatan gelatin. Hal ini sesuai pernyataan Gunawan et al. (2017) bahwa kecerahan gelatin ditentukan oleh bahan baku dan proses pembuatan gelatin. Gelatin pada umumnya diharapkan berwarna putih karena gelatin yang bermutu tinggi biasanya tidak berwarna, selain itu gelatin yang berwarna semakin putih semakin baik sehingga aplikasi bisa lebih luas.

Menurut Wiraatmaja (2006) warna putih kekuningan gelatin dikarenakan proses pengeringan juga dipengaruhi oleh kesegaran bahan baku. Selain itu juga warna gelatin berkaitan dengan tingkat efektifitas proses pretreatment yaitu pelepasan pigmen selama proses perendaman dengan larutan 
atau senyawa yang digunakan (Alhana et al., 2015). Meskipun proses perendaman dengan larutan mampu menarik pigmen dari bahan baku akan tetapi secara statistik perendaman dengan menggunakan jenis asam yang berbeda tidak memberikan pengaruh secara signifikan terhadap karakteristik warna gelatin tulang ikan tuna sirip kuning yang dihasilkan.

\section{Aroma}

Menurut Nurmilah dan Siti (2018) aroma yang dihasilkan dari gelatin tulang ikan berasal dari komponen senyawa folatil yang berasal dari bahan baku dan terperangkap selama proses pembuatan gelatin sehingga gelatin memiliki aroma yang khas. Hal ini juga didukung oleh penelitian Pratama et al. (2013) menunjukkan bahwa pada ikan terkandung senyawa folatil yang pada umumnya terdiri dari beberapa komponen penyusun diantaranya adalah aldehid, alkohol, keton dan hidrokarbon. Senyawa folatil ini akan berinteraksi dengan protein yang terkandung dalam ikan selama proses pengolahan sehingga menimbulkan aroma spesifik atau khas ikan yang terdapat pada gelatin.

\section{Uji Kimia}

\section{Kadar Air}

Perbedaan nilai kadar air gelatin pada penelitian ini diduga karena asam yang digunakan dalam penelitian ini yaitu asam klorida, asam asetat dan asam sulfat memiliki kemampuan yang berbedabeda dalam mengisolasi kolagen. Hal ini sesuai dengan pernyataan Ridhay et al. (2016), bahwa kadar air gelatin dipengaruhi oleh kemampuan jenis asam dalam mengisolasi kolagen tulang ikan.

Rendahnya kadar air pada gelatin dengan perendaman asam sulfat diduga karena kolagen yang terisolasi lebih banyak dibandingkan gelatin dengan perendaman asam klorida dan asam asetat. Hal ini diduga karena asam sulfat merupakan asam kuat dibandingkan asam klorida dan asam asetat, sehingga proses hidrolisis lebih optimal, yang menyebakan kadar air pada gelatin tulang ikan tuna dengan perendaman asam sulfat lebih rendah. Hal ini sesuai dengan peryataan (Wicaksono, 2017), bahwa asam dapat menyebabkan proses hidrolisis karena dapat mempercepat proses terpecahnya kadar air menjadi $\mathrm{H}_{+}$dan $\mathrm{OH}$ - sehingga kadar air pada tulang akan berkurang.

Nilai kadar air gelatin yang terbaik pada penelitian ini diperoleh pada gelatin dengan perendaman asam sulfat karena memiliki nilai yang lebih rendah, karena akan memperpanjang daya simpannya. Menurut Santoso et al. (2015) kadar air yang terkandung pada gelatin tulang ikan akan mempengaruhi daya tahan gelatin itu sendiri terhadap serangan mikroba. Kadar air pada penelitian ini masih memenuhi standar maksimum SNI 06-3735 (1995) yaitu $16 \%$. Penelitian sebelumnya pembuatan gelatin dari tulang ikan cakalang dengan perendaman asam asetat memiliki kadar air 3,72\% (Ridhay et al., 2016). Nurilmala et al. (2006) melaporkan bahwa gelatin dari tulang ikan tuna dengan perendaman asam klorida memiliki kadar air 6,54\%. Minah et al.(2016) juga menyatakan dalam penelitiannya bahwa gelatin dari tulang ikan tuna dengan perendaman asam sulfat memiliki kadar air 8,8-9,8\%. Kadar air komersial $12,21 \%$.

\section{Kadar Abu}

Kadar abu tertinggi pada penelitian ini diperoleh pada gelatin dengan perendaman asam klorida sedangkan terendah diperoleh pada gelatin dengan perendaman asam asetat. Tingginya kadar abu gelatin dengan perendaman asam klorida diduga karena terdapatnya kandungan kalsium yang ditandai dengan gelatin yang berwarna kuning keruh. Menurut Rosida et al. (2018), tingginya kalsium mengakibatkan warna gelatin dalam larutan menjadi keruh.

Perbedaan kadar abu gelatin pada penelitian ini, pada tiap-tiap perlakuan diduga dipengaruhi oleh perbedaan jenis asam yang digunakan ditiap perlakuan karena tiap-tiap asam yang digunakan memiliki kemampuan yang berbeda dalam hal mendegradasi mineral yang terdapat pada tulang hal ini sesuai dengan pernyataan Rahayu dan Fithriyah (2015) bahwa besar kecilnya kadar abu ditentukan pada saat demineralisasi. Semakin banyak kalsium yang larut pada proses demineralisasi, maka kadar 
abu akan semakin rendah. Pada proses tersebut asam akan bereaksi dengan kalsium fosfat pada tulang. Menurut Ridhay et al. (2016) proses demineralisasi yang berlangsung maksimal akan menyebabkan semakin banyak ikatan peptide dalam kolagen terpotong sehingga semakin besar mineral yang menempel pada ossein dan terlarut didalam larutan gelatin.

Nilai kadar abu gelatin pada penelitian ini melebihi standar maksimum yang telah ditetapkan oleh SNI 06-3735 (1995) yaitu 3,25\%. Hal ini diduga karena bahan baku yang digunakan adalah tulang ikan yang diketahui megandung banyak mineral. Hal ini sesuai dengan pernyataan Jones (1997) bahwa gelatin yang diekstrak dari tulang ikan mengandung banyak komponen-kompenen mineral seperti kalsium, klor, belerang, fosfor, natirum, dan magnesium. Mulyani (2011) menyatakan bahwa tingginya kadar abu pada gelatin karena masih adanya komponen mineral yang terikat pada kolagen dan belum terlepas saat pencucian sehingga terbawa pada gelatin yang dihasilkan.

Penelitian sebelumnya pembuatan gelatin dari tulang ikan tuna dengan perendaman asam klorida memiliki kadar abu 8,02\% (Panjaitan, 2016). Tazwir (2008) melaporkan bahwa gelatin dari tulang ikan kaci-kaci dengan perendaman asam asetat menghasilkan kadar abu sebesar 1,96\%. Nasution et al. (2018) juga manambahkan bahwa gelatin dari kulit ikan patin dengan perendaman asam sulfat memiliki kadar abu 0,19\%. Kadar abu gelatin komersial sebesar $1,66 \%$.

\section{Kadar Protein}

Nilai kadar protein tertinggi yaitu pada perlakuan $A 1$ (perendaman dengan asam klorida 4\%) yaitu $50,64 \%$ hal ini menunjukkan bahwa kadar protein gelatin hasil penelitian ini lebih rendah dari kadar protein tertinggi gelatin hasil penelitian Iqbal et al. (2015) yaitu sebesar $65,42 \%$ dan nilai kadar protein ini belum memenuhi standar yang telah ditetapkan oleh SNI 06-3735 (1995) yaitu 87, 35\%. Hal ini diduga karena perbedaan jenis asam yang digunakan dan suhu ekstraksi.Suhu ekstraksi yang digunakan pada penelitian ini $80^{\circ} \mathrm{C}$ sedangkan pada penelitian lqbal et al. (2015) $70^{\circ} \mathrm{C}$.

Menurut Junianto et al.(2006) kolagen dapat mengalami penyusutan jika dipanaskan diatas suhu penyusutan. Kondisi suhu ini akan memperpendek serat kolagen sebesar sepertiga atau seperempat dari panjang asalnya, proses penyusutan kolagen menyebabkan struktur kolagen pecah menjadi lilitan acak yang larut dalam air dan disebut dengan gelatin. Suhu penyusutan dimulai dari suhu $35^{\circ} \mathrm{C}$.

Kadar protein tertinggi pada penelitian ini diperoleh pada gelatin dengan perendaman asam klorida sedangkan terendah diperolah pada gelatin dengan perendaman asam sulfat.Tingginya protein pada gelatin dengan perendaman asam klorida diduga karena asam klorida mampu menghidrolisis kolagen dengan sempurna (Sasmitaloka et al., 2017).Hal ini sesuai dengan penyataan Zhang et al. (2016), bahwa asam klorida mampu menguraikan serat kolagen lebih banyak dan cepat tanpa mempengaruhi kualitas gelatin yang dihasilkan serta mengubah serat kolagen tripel heliks menjadi rantai tunggal.

\section{Derajat Keasaman (pH)}

Derajat Keasaman $(\mathrm{pH})$ merupakan salah satu parameter yang diterapkan dalam penentuan standar mutu gelatin. Pengukuran nilai $\mathrm{pH}$ gelatin penting dilakukan karena $\mathrm{pH}$ larutan mempengaruhi sifat-sifat gelatin lainnya seperti viskositas, kekuatan gel dan berpengaruh juga terhadap aplikasi gelatin dalam produk (Iqbal et al., 2015). Perbedaan nilai pH pada tiap perlakuan disebabkan karena perbedaan jenis asam yang digunakan pada saat ekstraksi. Nilai $\mathrm{pH}$ tertinggi diperoleh dari gelatin yang diekstraksi menggunakan asam klorida dan asam asetat sedangkan terendah diperoleh dari ekstraksi menggunakan asam sulfat.

Menurut Adiningsi dan Purwanti (2015) rendahnya nilai $\mathrm{pH}$ gelatin disebabkan karena asam sulfat merupakan asam kuat dibanding asam klorida dan asam asetat. Pada saat terjadi pengembangan kolagen waktu perendaman, banyak sisa asam yang tidak bereaksi terserap dalam kolagen yang mengembang dan terperangkap dalam jaringan fibril 
kolagen sehingga sulit dinetralkan pada saat pencucian yang akhirnya ikut terhidrolisis pada proses ekstraksi dan mempengaruhi tingkat keasaman gelatin.

Nilai $\mathrm{pH}$ yang didapatkan pada penelitian ini masih memenuhi standar gelatin yang di syaratkan oleh SNI 06-3735 (1995) 3,8-6,0. Nilai pH yang diperoleh pada penelitian ini tidak berbeda jauh dari beberapa penelitian sebelumnya. Adiningsih et al.(2015) melaporkan bahwa gelatin dari tulang ikan tenggiri dengan perendaman asam sulfat memiliki $\mathrm{pH}$ 3,5-4,0. Trilaksani et al. (2012) juga mengemukakan bahwa gelatin dari kulit ikan kakap merah dengan perendaman asam klorida memiliki pH 5,45. Gelatin dari kulit ikan tuna dengan perendaman asam asetat memiliki pH 4,50-5,01 (Agustin et al., 2015).

\section{KESIMPULAN}

Berdasarkan hasil penelitian dan pembahasan, maka dapat disimpulkan sebagai berikut :

1. Gelatin tulang ikan tuna sirip kuning diperoleh hasil terbaik uji sensori warna dengan perendaman menggunakan asam sulfat yaitu 6,1 dan uji sensori aroma dengan perendaman menggunakan asam klorida yaitu 6,2. Nilai kadar air berkisar antara 6,95\% - 12,51\%, kadar abu $4,53 \%-6,60 \%$, kadar protein $25,88 \%-50,64 \%$ dan $\mathrm{pH} 4-5$.

2. Total rendemen yang diperoleh berkisar antara 1,83-3 \%.

3. Penggunaan jenis asam yang berbeda tidak berpengaruh nyata terhadap aroma, warna, kadar air, kadar abu, kadar protein dan pH gelatin tulang ikan sirip kuning.

\section{DAFTAR PUSTAKA}

Adiningsih Y, dan Purwanti T. 2015. Karakteristik Mutu Gelatin Ikan Tenggiri (Scomberomorus commersonii) Dengan Perendaman Menggunakan Asam Sitrat dan Asam Sulfat. Balai Riset dan Standardisasi Industri Samarinda. Jurnal Riset Teknologi Industri, Vol. 9. No. 2.
Alhana, Suptijah P, Tarman K. 2015. Extrakction and Characterization of Collagen from Sea Cucumbar Flesh. Jurnal Pengolahan Hasil Perikanan Indonesia. 18(2): 150-161

Al-Saidi G, Mohammad SR, dan Ahmed A, Nejib G. 2010. Thermal Characteristics of Gelatin Extracted from Shaari Fish Skin (Effect of Extraction Conditions), Journal Therm Anal Calorim,104:593-6-3.

AOAC. 1995. Official Methods of Analysis of The Association of Official Analytical

[BPS] Badan Pusat Statistik. 2019. Volume dan Nilai Perdagangan Antar Pulau Hasil Perikanan Menurut Jenis Barang. Data sensus https://sultra.BPS.go.id/statictable.com.

[diakses pada 3 mei 2019]

Gunawan F,Suptijah P, Uju, 2017. Ekstraksi dan Karakterisasi Gelatin Kulit Ikan Tenggiri (Scomberomorus commersonii) dari Provinsi Kepulauan Bangka Belitung. Jurnal Pengolahan Hasil Perikanan Indonesia. 20(3): 568-581.

Hintelwaldner, R. 1977. Raw Materia Di dalam Ward, A. G. Courts The Sience and Technology of Gelatin. Academic Press. New York.

Iqbal M, Anam C, Ridwan AA. 2015. Optimasi Rendemen dan Kekuatan Gel Gelatin Ekstrak Tulang Ikan Lele Dumbo (Clarias gariepinus sp.). Fakultas Pertanian, Universitas Sebelas Maret. Surakarta. Jurnal Teknosains Pangan 4 (empat).

Jones, N.R.1997. Uses of gelatine in edible product, dalam Ward, A.G. \& Courts A. (Ed). The Science and Technology of Gelatine. New York: Academic Press.

Junianto, Kiki H, Ine M. 2006. Produksi Gelatin dari Tulang dan Pemanfaatannya sebagai Bahan Dasar Pembuatan Cangkang Kapsul. Jurnal Penelitian Hibah Bersaing IV Tahun I.

Lombu FV, Agustin AT, dan Pandey EV. 2015. Pemberian Konsentrasi Asam Asetat pada Mutu Gelatin Kulit Ikan Tuna. Jurnal Media Teknologi Hasil Perairan. 3(2): 25-28.

Minah NF, Maria D, dan Catur Pratiwi S. 2016. Ekstraksi Gelatin dari Hidrolisa Kolagen Limbah 
Tulang Ikan Tuna dengan Variasi Jenis Asam dan Waktu Ekstraksi. Seminar Nasional Inovasi dan Aplikasi Teknologi di Industri. Teknik Kimia Fakultas Teknologi Industri ITN Malang Jatim. Norland RE. 1990. Fish gelatin. In: Voight, M.N., Botta, J.K. (ed.). Advances in Fisheries Technology and Biotechnology for Increased Profitability. Lancaster, Pa.: Technomic Pub. Co.

Nurilmala M, Wahyuni M, Wiratmaja H. 2006.

Perbaikan Nilai Tambah Limbah Tulang lkan

Tuna (Thunnus sp.) Menjadi Gelatin Serta Analisis Fisika-Kimia. Buletin Teknologi Hasil Perikanan. 9(2): 22-33.

Nurilmala M, Agoes MJ, dan Rofi AD. 2017. Karakteristik Gelatin Kulit Ikan Tuna Sirip Kuning. Departemen Teknologi Hasil Perairan, Fakultas Perikanan dan IImu Kelautan, Institut Pertanian Bogor.JPHPI 2017, Volume 20 Nomor 2. Hal 339-350.

Nurmilah S, dan Mujdalipah S. 2018. Ekstrak Gelatin Tulang Ikan Kakap (L. Macolor niger) Menggunakan Metode Asam. Fakultas Pendidikan Teknologi dan Kejuruan Universitas Pendidikan Indonesia. Riset Agroindustri.

Panjaitan TFC. 2016. Optimasi Ekstraksi Dari Tulang Ikan Tuna (Thunnus albacares). Jurnal Wiyata. $3(1): 11-17$

Pratama, Wulandari, Supriadi A., dan Purwanto B. 2013. Pengaruh Defatting dan Suhu Ekstraksi Terhadap Karakteristik Gelatin Tulang Ikan Gabus. Jurnal: Fishtech. Vol.2 No.1

Rahayu. 2008. Indikator.

http://kimia.upi/utama/bahanajar/kuliah/indikato r.html. [diakses pada 18 juli 2019]

Rahayu F, dan Fithriyah NH. 2015. Pengaruh Waktu Ekstraksi Terhadap Rendemen Gelatin dari Tulang Ikan Nila Merah. Fakultas Tehnik Universitas Muhammadiyah Jakarta. Seminar Nasional Sains dan Teknologi.

Ridhay A, Musafira, Nurhaeni, Nurakhirawati, dan Khasanah NB. 2016. Pengaruh Variasi Jenis
Asam Terhadap Rendemen Gelatin dari Tulang Ikan Cakalang. Universitas Tadulako. Palu. Jurnal Riset Kimia 2 (dua) : 44-53

Rosida R, handayani L, dan Aprillian d. 2018. Pemanfaatan Limbah Tulang Ikan KambingKambing (Abalistes stellaris) Sebagai Gelatin Menggunkan Variasi Konsentrasi $\mathrm{CH}_{3} \mathrm{COOH}$. Universitas Abulyatama. Jurnal Aquatic Sains, Volume 5:2.

Santoso C, Surti T, dan Sumardianto. 2015. Perbedaan Penggunaan Konsentrasi Larutan Asam Sitrat Dalam Pembuatan Gelatin Tulang Rawan Ikan pari Mondol (Himantura gerrardi). Universitas diponegoro, Semarang. Jurnal Pengolahan dan Bioteknologi Hasil Perikanan, Volume 4. Nomor 2.

Sasmitaloka, K.S., Miskiyah, dan Juniawati. 2017. Kajian Potensi Kulit Sapi Kering Sebagai Bahan Dasar Produksi Gelatin Halal.BalaiBesar Litbang Pascapanen Pertanian : Bogor

SNI 06-3735. 1995. Mutu dan Cara Uji Gelatin. Dewan Standarnisasi Nasional. Jakarta.

Tazwir, N. Hak, R. Peranginangin. 2008. Ekstraksi Gelatin Dari Kulit Kaci-Kaci (Plecthorinchus flavomaculatu) Secara Asam dan Enzimatis. Laporan Teknis. Balai Besar Penelitian Pengolahan Produk dan Bioteknologi Kelautan dan Perikanan. Jakarta.

Trilaksani W., Mala N., dan Ima H. S. 2012. Ekstraksi gelatin kulit ikan kakap merah (Lutjanus sp.) dengan proses perlakuan asam. Institut Pertanian Bogor. JPHPI 2012 Volume 105 No.3 Wicaksono AS, 2017. Pemanfaatan Limbah Tulang Ikan Tongkol (Euthynnus affinis) sebagai Gelatin (Studi Konsentrasi Asam Khlorida dan Waktu Perendaman). [Skripsi]. Jurusan IImu dan Teknologi Pangan, Universitas Muhamadiyah Malang. Malang.

Wiraatmaja, H. 2006. Perbaikan Nilai Tambah Limbah Tulang Ikan Tuna (Thunnus sp.) Menjadi Gelatin serta Analisis Sifat fisiko-Kimia (Skripsi). Institut Pertanian Bogor, Bogor. 